\title{
The effect of initial weight of the ewe on later reproductive effort in domestic sheep (Ovis aries)
}

\author{
Geir Steinheim ${ }^{1 *}$, Atle Mysterud ${ }^{2}$, Øystein Holand ${ }^{1}$, Morten Bakken $^{1}$ and Tormod Ådnøy ${ }^{1}$ \\ ${ }^{1}$ Department of Animal Science, Agricultural University of Norway, P.O. Box 5025, N-1432 Ås, Norway \\ ${ }^{2}$ Department of Biology, Division of Zoology, University of Oslo, P.O. Box 1050 Blindern, N-0316 Oslo, Norway \\ (Accepted 18 February 2002)
}

\begin{abstract}
In ungulates, females typically need to reach a critical threshold body weight in order to reproduce. Females born in 'poor' years may lose 1 year of reproduction, as they reach the critical body mass 1 year later. Some studies report also a lasting effect of low initial body weight into prime age, while several other studies have shown that nearly all prime-age females ovulate or are pregnant. However, the quality of the offspring (as measured by offspring body weight) is often not considered. We tested whether female ungulates with an initially low body weight (at around weaning) reach the same reproductive output as females with higher initial weights, and thus whether or not they are able to compensate for their initial low weight. Data on body weight of 123533 lambs of domestic sheep Ovis aries from 73299 litters that in turn derived from 32359 different ewes were used. All ewes and lambs had been free-ranging on outlying pastures in Norway during the entire summer season. Ewes with an initially low body weight produced smaller offspring throughout their lifespan. Ewes with an initially low body weight also produced fewer lambs at first and second parturition, but lifetime number of offspring was not related to ewes' initial weight. We concluded that bigger was better: the smaller offspring of ewes with a low initial weight demonstrate a lasting cost on reproductive effort, with consequences for animal production systems and management of wild ungulates.
\end{abstract}

Key words: cohort effects, life history, litter size, Ovis aries

\section{INTRODUCTION}

Body size is one of the most important factors influencing life-history traits (Calder, 1984). In ungulates, females may need to reach a critical threshold body weight in order to reproduce (Reimers, 1983; Albon, Mitchell et al., 1986; Gaillard, Sempere et al., 1992; Langvatn et al., 1996; Putman et al., 1996; Gaillard, Festa-Bianchet, Delorme et al., 2000). Both densitydependent and density-independent factors, such as climate, can affect body growth and thus the population dynamics of large herbivores, though the relative role of these factors for reproduction and survival may vary considerably (reviews in Putman et al., 1996; Sæther, 1997; Gaillard, Festa-Bianchet \& Yoccoz, 1998, Gaillard, Festa-Bianchet, Yoccoz et al., 2000). Individuals from cohorts experiencing resource limitation due to high density (Putman et al., 1996; Forchhammer et al., 2001) or unfavourable weather conditions (Albon, Clutton-Brock \& Langvatn, 1992; Langvatn et al., 1996)

*All correspondence to: G. Steinheim.

E-mail: geir.steinheim@ihf.nlh.no in utero or as juveniles, grow slower, and attain the critical body mass necessary for reproduction at a later age (review in Lindström, 1999).

It has been claimed that the effect of severe conditions (resulting from either high density or harsh climate) during early development can persist into adulthood (Soay sheep Ovis aries: Coltman et al., 1999; Forchhammer et al. 2001; red deer Cervus elaphus: Albon, Clutton-Brock \& Guinness, 1987; Post, Stenseth et al., 1997; Post, Langvatn et al., 1999; bighorn sheep Ovis canadensis: Festa-Bianchet, Jorgenson \& Réale, 2000). This may be particularly evident for males of polygynous and dimorphic ungulate species, which keep growing for a much longer time than females (CluttonBrock, Guinness \& Albon, 1982; Coltman et al., 1999; Festa-Bianchet et al., 2000). For females the pattern is regarded as being somewhat different. Females born light, e.g. those born in 'poor' years, may lose 1 year of reproduction relative to the other females in the population, as they reach the critical body mass 1 year later (Langvatn et al., 1996). However, after the first reproductive event, there seem to be some contradictory opinions regarding the role of body weight in affecting 
reproductive effort of females. Several studies report that body mass during prime age does not affect variation in reproduction notably (Langvatn et al., 1996; Gaillard, Festa-Bianchet, Delorme et al., 2000). For example, in a Norwegian population almost all red deer hinds $>3$ years old ovulated (Langvatn et al., 1996), and in France $98 \%$ of all roe deer Capreolus capreolus does 2 years old or older were pregnant during winter (Gaillard, Sempere et al., 1992). The number of offspring raised by roe deer and bighorn sheep was not found to be related to female mass after the effect of longevity was accounted for (Gaillard, Festa-Bianchet, Delorme et al., 2000). However, some studies report an effect of body mass on female reproductive effort also after prime age is reached (red deer: Mitchell, 1973; reindeer Rangifer tarandus: Weladji et al., 2002). And even if nearly all prime-age females ovulate (red deer: Langvatn et al., 1996), are pregnant (roe deer: Gaillard, Sempere et al., 1992) and produce a similar number of offspring (roe deer: Gaillard, Festa-Bianchet, Delorme et al., 2000), the quality of the offspring (as measured by offspring body weight) may still be related to the initial body weight of the females. Large offspring tend to have better survival than smaller ones (red deer: Guinness, Clutton-brock \& Albon, 1978; Loison, Langvatn \& Solberg, 1999; fallow deer Dama dama: Asher \& Adam, 1985), and so it remains to be demonstrated that female ungulates after reaching the age of first reproduction have no further cost of an initial low body weight.

This study tested whether female ungulates with a low initial body weight reached the same reproductive output as females with an initially high body weight. Data were from the Norwegian Sheep Recording System, on body weight and litter sizes of lambs from 77958 litters of domestic sheep, where initial weight and age of the ewe is known. In Norway, sheep are freeranging on rangeland pastures all summer (Mysterud, Stenseth et al., 2001), and have a summer diet that is comparable to sympatric populations of red deer and reindeer (Mysterud, 2000). Hence, studies of Norwegian domestic sheep, for which detailed life-history data are available, may be useful in addressing general ecological problems, with relevance also for wild ungulates.

\section{MATERIALS AND METHODS}

\section{Study area and sheep husbandry practice}

Data come from the county of Buskerud in southern Norway (Fig. 1). In 2000 there were 813 sheep farms in Buskerud (Statistics Norway, 2002). In our study period from 1990 to 1999, as many farms as possible (according to the selection criteria given below) were included in the analyses. The resulting 334 farms were distributed evenly across the county.

During winter, sheep are kept indoors and fed both concentrates and roughage. Mating takes place in early winter. Approximately one-third of the ewe lambs are

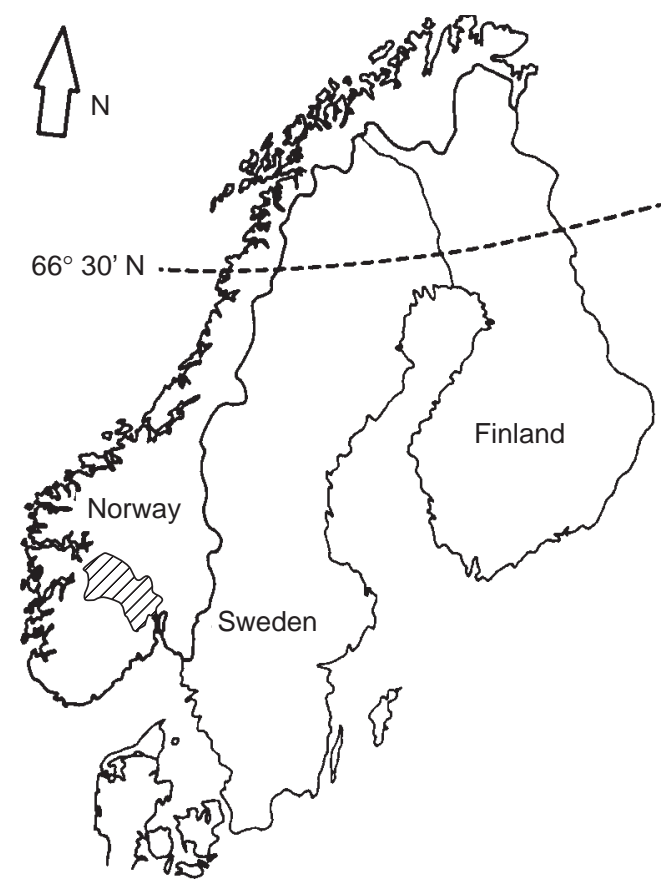

Fig. 1. The study area was Buskerud County, Norway (hatched). Total area, $14927 \mathrm{~km}^{2}$.

entered into the breeding stocks each year. Most of these are mated to produce lambs at 12 months of age. Lambs are born indoors in spring, and shortly after released onto pastures with their mothers who they will follow for the entire grazing season. During the summer period (from late June or early July to September), domestic sheep are truly free-ranging and graze in much the same way as sympatric populations of wild herbivores (Warren \& Mysterud, 1991; Warren et al., 1993). Most sheep graze in the alpine and sub-alpine zone (Garmo \& Skurdal, 1998). Stocking rates are generally low on Norwegian rangelands, roughly ranging from 5 to $50 \mathrm{sheep} / \mathrm{km}^{2}$ (Mysterud, 2000).

\section{Sheep data}

Only data on Dala sheep were included. Dala is the most common breed in Norway, and is especially dominant in Buskerud where it constituted $89 \%$ of all registered sheep during the study period. The following variables were retrieved from the Norwegian Sheep Recording System: age of ewe at parturition (years), initial weight $(\mathrm{kg})$ of ewe (together with initial weighing date, i.e. age in days), weaning weight ( $\mathrm{kg}$ ) of lambs, age of lambs at weighing (days), litter size at birth and at weaning, and, finally, year and farm. Data were only considered from ewes between 1 and 7 years of age, as most sheep are slaughtered before this age due to marked effects of senescence (Mysterud, Steinheim et al., 2002). Also, only litters where no lambs had been introduced (fostered lambs) or removed (for fostering or hand-rearing) by the farmer were included. As some sheep are gathered from the pastures early because of 
Table 1. Percentage of ewes Ovis aries being discarded from the breeding stocks between ewe breeding age $n$ and $n+1$ years, ewe initial weights assigned to one of four classes. Values based on age of all reproducing ewes of the analysed data set, e.g. between their first litter and the time of the second litter, $26 \%$ of the initially lightest ewes were discarded. Of the surviving ewes in this class, $40 \%$ were discarded after their second litter, etc.

\begin{tabular}{lllll}
\hline & \multicolumn{4}{l}{ Ewe initial weight $(\mathrm{kg})$} \\
\cline { 2 - 5 } $\begin{array}{l}\text { Ewe age } \\
\text { years: } \\
n-n+1\end{array}$ & $<41.0$ & $41.0-44.9$ & $45.0-48.9$ & $>48.9$ \\
\hline $1-2$ & 26 & 28 & 26 & 26 \\
$2-3$ & 40 & 35 & 34 & 33 \\
$3-4$ & 44 & 42 & 37 & 35 \\
$4-5$ & 48 & 43 & 41 & 40 \\
$5-6$ & 53 & 48 & 50 & 52 \\
$6-7$ & 71 & 73 & 74 & 71 \\
\hline
\end{tabular}

special circumstances, only lambs aged between 100 and 200 days at weighing were considered. Litters for which it was reported that $>3$ lambs followed their mother out to pasture were excluded from the dataset, as this suggest a highly uncommon management practice. Subsequently, the dataset included 123533 lambs from 73299 litters that in turn derived from 32359 different ewes.

The farmers' practice of recruiting and discarding breeding stock was not strongly related to initial weight of the ewe (Table 1), as might have been expected. The reason for this is possibly the correction methods used when calculating breeding values: initial weight is reduced for singles and augmented for triplets. There was, however, some tendency towards ewes with a high initial weight being discarded at an older age than ewes with a low initial weight.

\section{Statistical analyses}

General linear mixed models (Littell et al., 1996; for an application, see Milner, Elston \& Albon, 1999) were used, with the interaction term between year and farm as a random factor in all models to avoid pseudoreplication. Two separate models were run to explain variation.

(1) Litter size at autumn/around weaning:

littersize $_{\mathrm{AUTUMN}}=\operatorname{age}_{\mathrm{EWE}}+$ initial weight $_{\mathrm{EWE}}$ $\left(\right.$ age $\left._{\mathrm{EWE}}\right)+$ farm* year + error

(2) Live autumn weight/weaning weight of lamb:

weight $_{\mathrm{LAMB}}=$ age $_{\mathrm{EWE}}+$ initial weight $_{\mathrm{EWE}}\left(\right.$ age $\left._{\mathrm{EWE}}\right)+$ $\operatorname{sex}_{\mathrm{LAMB}}+\mathrm{age}_{\mathrm{LAMB}}+$ littersize + farm $*$ year + error

Predictor variables in both models were the reproducing ewe age classes (age ${ }_{E W E}: 1,2, \ldots, 7$ years), ewe initial weight within ewe age class ((initial weight EWE $_{\text {(a- }}$ $\left.\mathrm{ge}_{\mathrm{EWE}}\right)$ ), after correcting for age (in days) on initial weight of ewe for using linear regression and the random term farm*year (2157 in all, from 334 farms during 1990-99, both class variables). Adding this

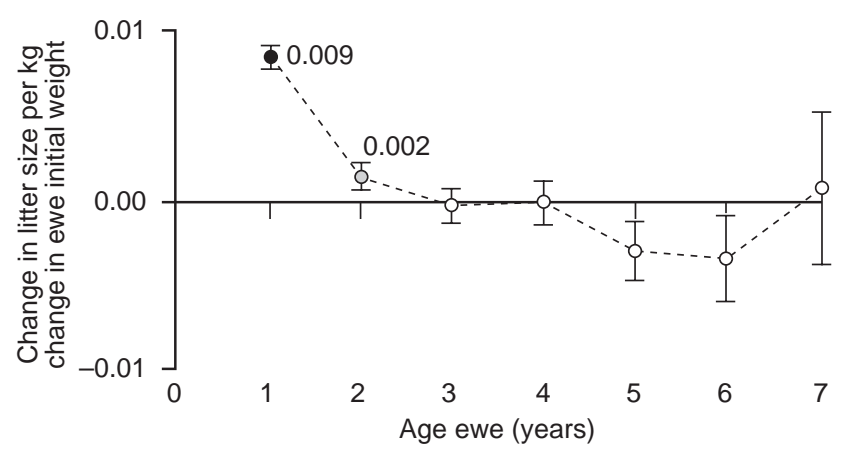

Fig. 2. Corrected change in litter size $( \pm \mathrm{SE})$ per $\mathrm{kg}$ increase in initial weight of ewe Ovis aries. Solid black circle, $P<0.01$ (for $t$-tests of estimate $\neq 0$ ); grey circle, $P=0.04$; all other $P>0.10$. Estimate given where $P<0.05$.

random factor takes the dependency between lambs in the same flock and year into account. In both models the residual variance is termed error. The effect of repeated observations on the same ewe is not modelled, and this may inflate the error term somewhat. In the 'lamb weaning weight model' (2) sex of lamb ( $\operatorname{sex}_{\text {LAMB }}$ : ewe or ram, class variable), litter size at release to pastures (littersize: 1, 2 or 3 lambs, class variable), and age of lamb at weighing (age LAMB : 100-200 days, covariate variable) were added.

All analyses were carried out using the mixed procedure in SAS, version 6.12 (Littel et al., 1996). This procedure uses a restricted maximum likelihood (REML) method of estimation.

\section{RESULTS}

Litter size in autumn was significantly influenced by initial weight of ewe within ewe age classes (d.f. = $71000, F=25.19, P<0.01)$. This effect was significant for ewes aged 1 year (d.f. $=71000, t=12.99, P<0.01$; Fig. 2) and two years (d.f. $=71000, t=2.01, P=0.04$ ). A $1 \mathrm{~kg}$ increase in initial weights the ewes were estimated to increase litter size with on average 0.009 and 0.002 lambs, respectively, for 1- and 2-year-old ewes. This is equivalent to saying that an increase in ewe initial weight by $10 \mathrm{~kg}$ should cause one out of 111 -year-old ewes to produce one more lamb, while the corresponding result for 2-year-old ewes was one out of 50 . When totalling the effect of initial weight of ewe within ewe age, over all ages, the estimate was weakly positive, but not significantly different from zero (d.f. $=71000$, $t=0.88, P=0.38$ ), i.e. averaged across ewe ages, the initial weight of the ewe had no effect on the total number of lambs produced.

The main effect of age of ewe was significantly (d.f. $=71000, F=109.25, P<0.01$ ) related to litter size around weaning age, and least square means $( \pm \mathrm{SE})$ for litter size in the ewe age classes were: 1 year, 1.33 $( \pm 0.01) ; 2$ years, $1.79( \pm 0.01) ; 3$ years, $1.93( \pm 0.01)$; 4 years, $1.97( \pm 0.01)$; 5 years, $1.95( \pm 0.010)$ : 6 years, $1.92( \pm 0.01) ; 7$ years, $1.82( \pm 0.03)$. 


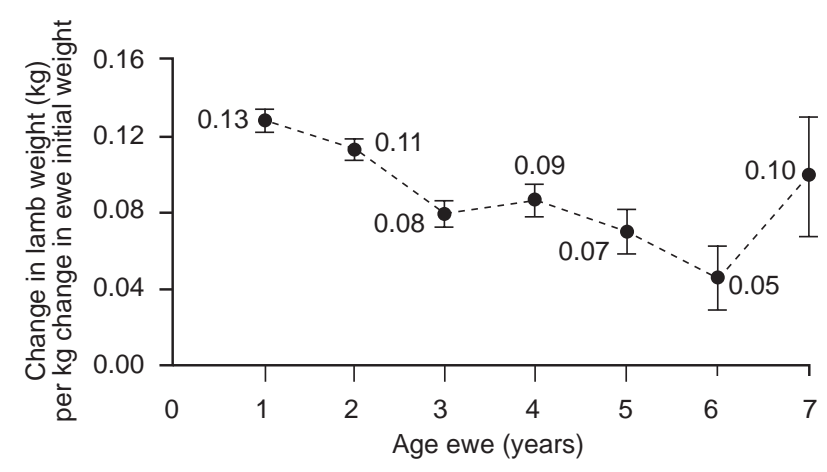

Fig. 3. Corrected change $(\mathrm{kg} \pm \mathrm{SE})$ in individual lamb weaning weight per $\mathrm{kg}$ increase in initial weight of ewe Ovis aries. All $P<0.01$ (for $t$-tests of estimate $\neq 0$ ).

Estimated variance components for the interaction between farm and year (farm*year) and for the error term (error) were 0.03 and 0.34 , respectively.

The autumn weights of lambs were significantly affected by initial ewe weight within ewe age (d.f. $=120000 ; F=167.08 ; P<0.001$ ). Estimates of this effect (Fig. 3) were significantly different from zero for all ewe ages (for $1-5$ years: d.f. $=120000$; all $t>6.2$; all $P<0.01$; for ages 6 years: d.f. $=120000, t=2.8$, $P<0.01$; for 7 years: d.f. $=120000, t=3.3, P<0.01$ ). A $1 \mathrm{~kg}$ increase in the initial weight of a ewe, made her produce lambs that were each $0.09 \mathrm{~kg}$ heavier, when considered throughout all seven ewe age classes (d.f. $=120000, t=15.65, P<0.01)$.

The main effect of age of ewe had a significant effect (d.f. $=120000, F=166.44, P<0.001$ ) on lamb weight, and least square means $( \pm \mathrm{SE})$ for lamb weight in the ewe age classes were: 1 year, $38.87( \pm 0.09) \mathrm{kg} ; 2$ years, 44.86 $( \pm 0.09) \mathrm{kg} ; 3$ years, $46.57( \pm 0.09) \mathrm{kg} ; 4$ years, 46.81 $( \pm 0.09) \mathrm{kg} ; 5$ years, $46.62( \pm 0.10) \mathrm{kg} ; 6$ years, 45.92 $( \pm 0.12) \mathrm{kg}$, and 7 years, $45.25( \pm 0.19) \mathrm{kg}$. Ram lambs were $4.14 \mathrm{~kg}$ heavier than ewe lambs (d.f. $=120000$, $F=17787.10, P<0.01)$. The effect of age of lamb was also significant (d.f. $=120000, F=10225.10, P<0.01$ ), with the weight increasing $0.19 \mathrm{~kg} / \mathrm{day}$ around weaning. Single lambs and twin lambs were, respectively, $12.75 \mathrm{~kg}$ and $5.55 \mathrm{~kg}$ heavier than triplets (d.f. $=120000$, $F=20541.61, P<0.001)$.

Estimated variance components for the interaction between farm and year and the error term were 13.12 and 29.16, respectively, for model (2).

\section{DISCUSSION}

Body size has long been identified as a major determinant of the reproductive effort of female ungulates (Hamilton \& Blaxter, 1980; Reimers, 1983; Albon, Mitchell et al., 1986; Gaillard, Sempere et al., 1992; Hewison, 1996; Langvatn et al., 1996; Putman et al., 1996; Gaillard, Festa-Bianchet, Delorme et al., 2000). It is often stated that in female ungulates, after primiparity is reached, no further cost of low initial weight exists (Gaillard, Sempere et al., 1992; Langvatn et al., 1996), and that lifetime reproductive success is therefore closely related to longevity (Gaillard, Festa-Bianchet, Delorme et al., 2000), as there is little variation in reproduction between prime-aged females. Our results show, however, that domestic ewes with a high initial body weight reared larger lambs in subsequent years (Fig. 3). Some of this may be the result of the lambs receiving genes from their dams that confer better growth potential. However, this genetic effect should remain the same irrespective of the age of the ewe. Our results show a consistent reduction in the effect of initial weight of the ewe on the weaning weight of her lambs from ewes aged 1-6 years. Therefore, we conclude that there is an effect of the ewe weight that is not linked to gene transmission, and that environmental, growthrelated conditions during the first months of a ewe's life have an effect on its lifelong production of offspring. Further studies should include estimations of genetic parameters and the potential of interactions between genetic and environmentally induced life-history effects.

Lifetime reproductive success of females has usually been measured as number of weaned offspring (Gaillard, Festa-Bianchet, Delorme et al., 2000), as large datasets on the body weight of offspring are inherently difficult to obtain. Our results show that the number of lambs weaned for ewes aged 2-6 years was not significantly related to the initial weight of the ewe. But, 1 -year-old ewes that were heavy as lambs the previous autumn, produced a significantly larger number of offspring. These results are in agreement with previous studies identifying the age at primiparity as an especially important phase in the life history of ungulates (Langvatn et al., 1996; Gaillard, Festa-Bianchet, Delorme et al., 2000), though body weight may also affect reproductive effort at prime age (Mitchell, 1973). The initial weight of the ewe was found to be related to litter size also for 2-year-old ewes; while significant, this effect was small compared to that on the size of the litters of the youngest ewes.

The lasting effect of initial weight of the ewe on the body weight of her lambs in all subsequent litters may affect subsequent offspring survival (Soay sheep: Clutton-Brock, Price et al., 1992; red deer: Guinness et al., 1978; Loison et al., 1999; fallow deer: Asher \& Adam, 1985). For the lightest ewes, this may possibly lead to a reduced lifetime reproductive success, even after the effect of longevity is accounted for. To investigate these questions further, post-weaning survival of the offspring needs to be studied in detail, to see at what age the offspring die of natural and or artificial causes.

Domestic animals obviously have a different evolutionary history than wild ungulates (Clutton-Brock, 1981). For example, domestic sheep have been artificially selected for large litter size, and this could exaggerate some life-history trade-offs (Mysterud, Steinheim et al., 2002), as expected from Beilhartz's (1994) model. Still, life-history characters do seem to be quite stable in an evolutionary context (Harvey \& Nee, 1997), and while intensities and threshold values might 
be altered, behavioural traits in general are not likely to change qualitatively during a domestication process (Price, 1998). Also, ever since their introduction at c. 5000-6000 вP (Drabløs, 1997), Norwegian domestic sheep have continuously been exposed to a substantial degree of natural selection when on outlying pastures, more so than other livestock species in Norway. Our results are thus of relevance not only to the livestock industry, but also to the understanding of life-history adaptations of ungulates in general. Furthermore, the differences known to exist between wild and domestic livestock, especially in reproductive output, sexual maturation and senescence (Price, 1998; Mysterud, Steinheim et al., 2002), represent exciting opportunities for hypothesis testing in comparative studies of ungulate life-history adaptations.

\section{Acknowledgements}

We gratefully acknowledge the financial support of the Research Council of Norway to GS (Project No 113409/ 720 ) and AM (Project No 129208/720). Thanks to W. J. Fjellstad for valuable comments to a previous draft of the paper.

\section{REFERENCES}

Albon S. D., Clutton-Brock, T. H. \& Guinness, F. E. (1987). Early development and population dynamics in red deer. II. Density-independent effects and cohort variation. J. Anim. Ecol. 56: 69-81.

Albon, S. D., Clutton-Brock, T. H. \& Langvatn, R. (1992). Cohort variation in reproduction and survival: implications for population demography. In The biology of deer: 15-21. Brown, R. D. (Ed.). New York: Springer Verlag.

Albon, S. D., Mitchell, B., Huby, B. J. \& Brown, D. (1986). Fertility in female red deer (Cervus elaphus): the effects of body composition, age and reproductive status. J. Zool. (Lond.) 209: 447-460.

Asher, G. W. \& Adam, J. L. (1985). Reproduction of farmed red and fallow deer in northern New Zealand. In Biology of deer production. Fennessy, P. F. \& Drew, K. R. (Eds). R. Soc. N. Z. Bull. 22: 217-224.

Beilhartz, R. G. (1994). Environmental limitations - consequences for breeding programs. Proceedings of the $5^{\text {th }}$ World Congress on genetics applied to livestock production. Smith, C. (Ed.). 18: 213-216. Guelph, Ontario, Canada: The Organising Committee.

Calder, W. A. (1984). Size, function, and life history. Cambridge, MA: Harvard University Press.

Clutton-Brock, J. (1981). Domestic animals from early times. London: Heinemann and British Museum (Natural History).

Clutton-Brock, T. H., Guinness, F. E. \& Albon, S. D. (1982). Red deer. Behaviour and ecology of two sexes. Edinburgh: Edinburgh University Press.

Clutton-Brock, T. H., Price, O. F., Albon, S. D. \& Jewell, P. A. (1992). Early development and population fluctuations in Soay sheep. J. Anim. Ecol. 61: 381-396.

Coltman, D. W., Smith, J. A., Bancroft, D. R., Pilkington, J., MacColl, A. D. C., Clutton-Brock, T. H. \& Pemberton, J. M. (1999). Density-dependent variation in lifetime breeding success and natural and sexual selection in Soay rams. Am. Nat. 154: 730-746.
Drabløs, D. (1997). Soga om smalen: jubileumsskrift Norsk sauog geitalslag 1947-1997 (The tale of the sheep: festschrift for the Norwegian sheep and goat breeders' association 1947-1997). Oslo: Norsk sau og geitalslag.

Festa-Bianchet, M., Jorgenson, J. T. \& Réale, D. (2000). Early development, adult mass, and reproductive success in bighorn sheep. Behav. Ecol. 11: 633-639.

Forchhammer, M. C., Clutton-Brock, T. H., Lindström, J. \& Albon, S. D. (2001). Climate and population density induce long-term cohort variation in a northern ungulate. J. Anim. Ecol. 70: 721-729.

Gaillard, J.-M., Festa-Bianchet, M. \& Yoccoz, N. G. (1998). Population dynamics of large herbivores: variable recruitment with constant adult survival. Trends Ecol. Evol. 13: 58-63.

Gaillard, J.-M., Festa-Bianchet, M., Delorme, D. \& Jorgenson, J. (2000). Body mass and individual fitness in female ungulates: bigger is not always better. Proc. R. Soc. Lond. B Biol. Sci. 267: 471-477.

Gaillard, J.-M., Festa-Bianchet, M., Yoccoz, N. G., Loison, A. \& Toigo, C. (2000). Temporal variation in fitness components and population dynamics of large herbivores. Annu. Rev. Ecol. Syst. 31: $367-393$.

Gaillard, J.-M., Sempere, A. J., Boutin, J.-M., Van Laere, G. \& Boisaubert, B. (1992). Effects of age and body weight on the proportion of females breeding in a population of roe deer (Capreolus capreolus). Can. J. Zool. 70: 1541-1545.

Garmo, T. H. \& Skurdal, E. (1998). Sauen på utmarksbeite In Saueboka: 159-202. Dahl, S. \& Lystad, M. L. (Eds). Oslo: A/S Landbruksforlaget.

Guinness, F. E., Clutton-Brock, T. H. \& Albon, S. D. (1978). Factors affecting calf mortality in red deer. J. Anim. Ecol. 47: 817-832.

Hamilton, W. J. \& Blaxter, K. L. (1980). Reproduction in farmed red deer 1. Hind and stag fertility. J. Agric. Sci., Camb. 95: 261-273.

Harvey, P. H. \& Nee, S. (1997). The phylogenetic foundations of behavioural ecology. In Behavioural ecology: an evolutionary approach: 334-349. 4th edn. Krebs, J. R. \& Davies, N. B. (Eds). Oxford: Blackwell Science.

Hewison, A. J. M. (1996). Variation in the fecundity of roe deer in Britain: effects of age and body weight. Acta Theriologica 41: 187-198.

Langvatn, R., Albon, S. D., Burkey, T. \& Clutton-Brock, T. H. (1996). Climate, plant phenology and variation in age at first reproduction in a temperate herbivore. J. Anim. Ecol. 65: $653-670$

Lindström, J. (1999). Early development and fitness in birds and mammals. Trends Ecol. Evol. 14: 343-348.

Littell, R. C., Milliken, G. A., Stroup, W. W., Russell, D. \& Wolfinger, R. D. (1996). SAS system for mixed models. Cary, NC: SAS Institute.

Loison, A., Langvatn, R. \& Solberg, E. J. (1999.) Body mass and winter mortality in red deer calves: disentangling sex and climate effects. Ecography 22: 20-30.

Milner, J. M., Elston, D. A. \& Albon, S. D. (1999). Estimating the contributions of population density and climatic fluctuations to interannual variation in survival of Soay sheep. J. Anim. Ecol. 68: $1235-1247$.

Mitchell, B. (1973). The reproductive performance of wild Scottish red deer, Cervus elaphus. J. Reprod. Fert. (Suppl.) 19: 271-285.

Mysterud, A. (2000). Diet overlap among ruminants in Fennoscandia. Oecologia (Berl.) 124: 130-137.

Mysterud, A., Steinheim, G., Yoccoz, N. G., Holand, Ø. \& Stenseth, N. C. (2002). Early onset of reproductive senescence in domestic sheep (Ovis aries). Oikos. 97: 177-183.

Mysterud, A., Stenseth, N. C., Yoccoz, N. G., Langvatn, R. \& Steinheim, G. (2001). Non-linear effects of large-scale climatic variability on wild and domestic herbivores. Nature (Lond.) 410: 1096-1099. 
Post, E., Langvatn, R., Forchhammer, M. C. \& Stenseth, N. C. (1999). Environmental variation shapes sexual dimorphism in red deer. Proc. Natl Acad. Sci. USA 96: 4467-4471.

Post, E., Stenseth, N. C., Langvatn, R. \& Fromentin, J.-M. (1997). Global climate change and phenotypic variation among red deer cohorts. Proc. R. Soc. Lond. B Biol. Sci. 264: 1317-1324.

Price, E. O. (1998). Behavioral genetics and the process of animal domestication. In Genetics and the behavior of domestic animals: 2-31. Grandin, T. (Ed.). San Diego: Academic Press.

Putman, R. J., Langbein, J., Hewison, A. J. M. \& Sharma, S. K. (1996). Relative roles of density-dependent and densityindependent factors in population dynamics of British deer. Mammal Rev. 26: 81-101.

Reimers, E. (1983). Reproduction in wild reindeer in Norway. Can. J. Zool. 61: 211-217.

Sæther, B.-E. (1997). Environmental stochasticity and population dynamics of large herbivores: a search for mechanisms. Trends Ecol. Evol. 12: 143-149.

Statistics Norway (2002). Driftseiningar i alt med husdyr og driftseiningar med ymse husdyrslag per 31. desember 2000, etter fylke (Holdings keeping livestock in Norway and holdings keeping livestock of different kinds) (WWW document). URL [http://www. ssb. no/emner/10/04/10/jordhus/tab-2001-07-1301. html].

Warren, J. T. \& Mysterud, I. (1991). Summer habitat use and activity patterns of domestic sheep on coniferous range in southern Norway. J. Range Manage. 44: 2-6.

Warren, J. T., Mysterud, I., Stensli, O. M., Berg, M. \& Movik, E. (1993). Use of forest vegetation by sheep as recorded by radio telemetry. Acta Agric. Scand. Sect. A. Anim. Sci. 43: 190-192.

Weladji, R. B., Mysterud, A., Holand, Ø. \& Lenvik, D. (2002). Age-related reproductive effort in reindeer (Rangifer tarandus): evidence of senescence. Oecologia (Berl.) 131: 79-82. 